\title{
Belowground Influence of Rhizobium Inoculant and Water Hyacinth Composts on Yellow Bean Infested by Aphis fabae and Colletotrichum lindemuthianum under Field Conditions
}

\author{
Victoria Naluyange ${ }^{1}$, Dennis M. W. Ochieno ${ }^{1}$, Philip Wandahwa ${ }^{2}$, Martins Odendo ${ }^{3}$, John M. Maingi ${ }^{4}$, Alice \\ Amoding ${ }^{5}$, Omwoyo Ombori ${ }^{4}$, Dative Mukaminega ${ }^{6} \&$ John Muoma $^{1}$ \\ ${ }^{1}$ Department of Biological Sciences, Masinde Muliro University of Science and Technology (MMUST), \\ Kakamega, Kenya \\ ${ }^{2}$ School of Agriculture, Veterinary Science and Technology, Masinde Muliro University of Science and \\ Technology (MMUST), Kakamega, Kenya \\ ${ }^{3}$ Socio-Economics and Statistics Division, Kenya Agricultural and Livestock Research Organization (KALRO), \\ Kakamega, Kenya \\ ${ }^{4}$ Department of Plant and Microbial Sciences, Kenyatta University, Nairobi, Kenya \\ ${ }^{5}$ Department of Soil Science, Makerere University, P. O. Box 7062, Kampala, Uganda \\ ${ }^{6}$ Faculty of Applied Sciences, Kigali Institute of Science and Technology (KIST), P.O. Box 3900, Kigali, \\ Rwanda \\ Correspondence: Victoria Naluyange, Department of Biological Sciences, Masinde Muliro University of Science \\ and Technology (MMUST), P.O. Box 190-50100, Kakamega, Kenya. E-mail: vicluy@gmail.com
}

Received: March 9, 2016 Accepted: April 14, 2016 Online Published: April 22, 2016

doi:10.5539/jps.v5n2p32 URL: http://dx.doi.org/10.5539/jps.v5n2p32

\begin{abstract}
Rhizobium inoculant has been developed for bean production in Lake Victoria basin. Two types of compost have been developed, water hyacinth compost with cattle manure culture $(\mathrm{H}+\mathrm{CMC})$ or with effective microbes (H+EM). Influence of Rhizobium and composts on Aphis fabae and Colletotrichum lindemuthianum were investigated in the field. Rhizobium and hyacinth composts increased nodulation $(\times 2$ to 5); while Aphis fabae population increased $(\times 2)$ on Rhizobium-inoculated plants with $\mathrm{H}+\mathrm{EM}$. Incidence of $C$. lindemuthianum was high in Rhizobium-inoculated plants. Plants that received diammonium phosphate (DAP) fertilizer had few nodules, reduced germination, slow growth and low yields. In conclusion, the water hyacinth composts contain beneficial microbes that promote root nodulation by Rhizobium, which is necessary for nitrogen fixation, while enhancing tolerance to aboveground infestations by $A$. fabae and $C$. lindemuthianum. We raise questions on our results to stimulate research, considering that bean breeding programs in Africa have mainly focused on microbial pathogens, and not insect pests.
\end{abstract}

Keywords: anthracnose, compost, manure, soil fertility, sustainability

\section{Introduction}

Common bean Phaseolus vulgaris is an important food security crop, and the major source of plant protein within the Lake Victoria basin in East Africa (David \& Sperling, 1999). Beans complement the shortage of animal protein in East Africa, especially in the prevailing situation whereby fish production has been greatly impeded by the disastrous spread of water hyacinth in Lake Victoria (Ntiba et al., 2001; Hecky et al., 2010). The leguminous crop is also very important in agro-ecosystems, as it symbiotically fixes nitrogen through endophytic Rhizobium species (Bala et al., 2011; Devi et al., 2013). However, bean production has been declining to levels that are too low to meet the demand in East Africa (Mauyo et al., 2007). The main causes of declines in bean production are inferior germplasms, low soil fertility, pests and diseases (David \& Sperling, 1999; Danielsen et al., 2013; Tittonell \& Giller, 2013). Depletion of soil nutrients such as nitrogen and phosphorus has been a growing problem for bean production in East Africa (Kimani et al., 2007, 2008; Ayuke et al., 2011). Insect pests such as the black bean aphid Aphis fabae have been transmitting viral diseases (Beebe, 2012; Were et al., 2013), while fungal pathogens such as Colletotrichum lindemuthianum cause anthracnose disease of beans in East 
Africa (Beebe, 2012; Kharinda, 2013). These factors have been complicated by the fact that local cultivars that are widely grown by smallholder farmers in East Africa have been succumbing to a complex of biotic and abiotic stresses (Otsyula et al., 2004; Ojiem et al., 2006; Kharinda, 2013).

There have been efforts to enhance sustainable crop production on farmlands in the Lake Victoria basin (Mireri et al., 2007; de Graaff et al., 2011), while conserving the lake for fish production (Lung'ayia et al., 2001; Nunan, 2013). Among the strategies, Rhizobium inoculants are being developed to enhance legume production by fixing nitrogen in the Lake Victoria basin (Bala et al., 2011). At the same time, nutrient-rich water hyacinth in the heavily eutrophied lake is being processed into compost, and transferred onto nutrient depleted farmlands for crop production (Naluyange et al., 2014). Removal of water hyacinth from Lake Victoria restores conditions that are favorable for fishing. Furthermore, water hyacinth compost contains phosphorus (Gunnarsson \& Petersen, 2007; Naluyange et al., 2014), which is necessary for nodulation and nitrogen fixation in Rhizobium-inoculated bean seeds (Ssali \& Keya, 1983), through processes such as enhancement of plant growth (Robson et al., 1981), improvement of shoot metabolism (Jakobsen, 1985) and specific roles in nodule initiation, growth and function (Israel, 1987). Such specific roles of phosphorus include ATP synthesis for nodule development and function (Ribet \& Drevon, 1996), as well as for signal transduction and cell membrane biosynthesis (Graham \& Vance, 2003). Rhizobium-inoculated beans are being promoted for improved yields and nitrogen fixation in the Lake Victoria region (Kihara et al., 2010; Thuita et al., 2012).

Rhizobium inoculants, when applied on legumes, have belowground effects such as enhanced root nodulation associated with better plant growth (Graham \& Vance, 2000). Such beneficial processes of Rhizobium are affected by biotic factors like rhizosphere microbes (van Veen et al., 1997) as well as abiotic factors like soil fertility (Rotaru \& Sinclair, 2009). Belowground colonization of roots by Rhizobium has been found to interact with aphids and other aboveground herbivores (Kempel et al., 2009; Katayama et al., 2010, 2011; Martinuz et al., 2012). For example, root colonization by Rhizobium has been found to promote plant resistance to insect pests (Thamer et al., 2011). However, Rhizobium colonization of roots has also been related to an increase in aphid and fungal incidences on leguminous shoots, which has been attributed to improved nutritive suitability of the host plant due to nitrogen fixation (Dean et al., 2009, 2014; Naluyange et al., 2014). Such effects of Rhizobium on legumes are modified by soil fertility amendments (El-Wakeil \& El-Sebai, 2009; Dean et al., 2009). For instance, Rhizobium when applied using water hyacinth compost as an inoculant carrier improves the growth of faba bean (Mohamed \& Abdel-Moniem, 2010).

In the Lake Victoria basin, combined application of water hyacinth compost and commercial Rhizobium inoculant had some positive effects on performance of the commercial Rosecoco bean cultivar, depending on the water hyacinth compost formulation (Naluyange et al., 2014). However, farmers in the Lake Victoria basin, especially in Western Kenya, mostly rely on local bean cultivars obtained from the market, including the yellow bean 'Mugasa' (David \& Sperling, 1999; Otsyula et al., 2004). Bean seeds from the local markets attain higher germination percentage than the certified commercial varieties (Otsyula et al., 2004). Furthermore, smallholder farmers in the Lake Victoria region rarely coat their seeds with fungicides that are always present in the commercial seeds. The absence of fungicides in the local bean seeds makes them ideal for Rhizobium inoculation, since such chemicals are potentially harmful to the inoculants (Graham \& Vance, 2000; Stoddard et al., 2010). However, unlike commercial bean cultivars, the yellow bean is among local cultivars that are yet to be studied, especially in terms of Rhizobium nodulation and pest infestations under the influence of soil fertility amendments such as water hyacinth compost.

The objective of this study was to determine the influence of Rhizobium inoculant and water hyacinth composts on the performance of yellow bean in terms of growth and yields, and how these applications affect natural infestation of the plants by $A$. fabae and $C$. lindemuthianum. We hypothesize that water hyacinth composts and Rhizobium inoculant contain plant growth promoting microbes that improve belowground nutrient acquisition for yellow bean growth and yields, enabling the plants to tolerate aboveground infestations by $A$. fabae and $C$. lindemuthianum.

\section{Materials and Methods}

\subsection{Experimental Design}

The field experiment was conducted at the Masinde Muliro University of Science and Technology farm (N 00 $17.104^{\prime}$, E $034^{\circ} 45.874^{\prime}$; altitude $1561 \mathrm{~m}$ a.s.1.). Soils in this region have been classified as dystro-mollic Nitisols (FAO, 1974; Rota et al., 2006). Nutrient composition for the soil was; total phosphorus (18.9 ppm), total nitrogen $(0.26 \%)$, organic carbon $(2.5 \%)$, potassium $\left(0.41 \mathrm{cmol}_{\mathrm{c}} \mathrm{kg}^{-1}\right)$, sodium $\left(0.1 \mathrm{cmol}_{\mathrm{c}} \mathrm{kg}^{-1}\right)$, calcium $\left(2.3 \mathrm{cmol}_{\mathrm{c}} \mathrm{kg}^{-1}\right)$, magnesium $\left(0.8 \mathrm{cmol}_{\mathrm{c}} \mathrm{kg}^{-1}\right)$, zinc $(1.9 \mathrm{ppm})$ and iron $(0.37 \mathrm{ppm})$, with acidic $\mathrm{pH}$ of 4.2 (Naluyange et al., 2014). 
The experiment was laid out in a randomized block design comprising $2 \times 4$ factorial treatments with Rhizobium inoculum factor having two levels (with or without inoculation) and fertility factor with four levels i.e. no fertilizer (Non), diammonium phosphate fertilizer-DAP (18-46-0), water hyacinth compost + cattle manure culture $(\mathrm{H}+\mathrm{CMC})$, and water hyacinth compost + effective microbes $(\mathrm{H}+\mathrm{EM})$. Each of the resulting 8 treatment combinations (plots) had 25 plants (n) in 3 blocks (i.e. $N=600$ ). Each plot was in form of a row containing the 25 plants spaced at $20 \mathrm{~cm}$, with a distance of $40 \mathrm{~cm}$ between the plots, without border rows. The treatment rows were completely randomized to minimize non-experimental bias in sampling for natural infestations of aphids and anthracnose disease on bean plants. This experiment was conducted during the long rain season between $20^{\text {th }}$ April to $30^{\text {th }}$ July 2012, and then repeated between $30^{\text {th }}$ May and $31^{\text {st }}$ August 2012 (Figure 1).

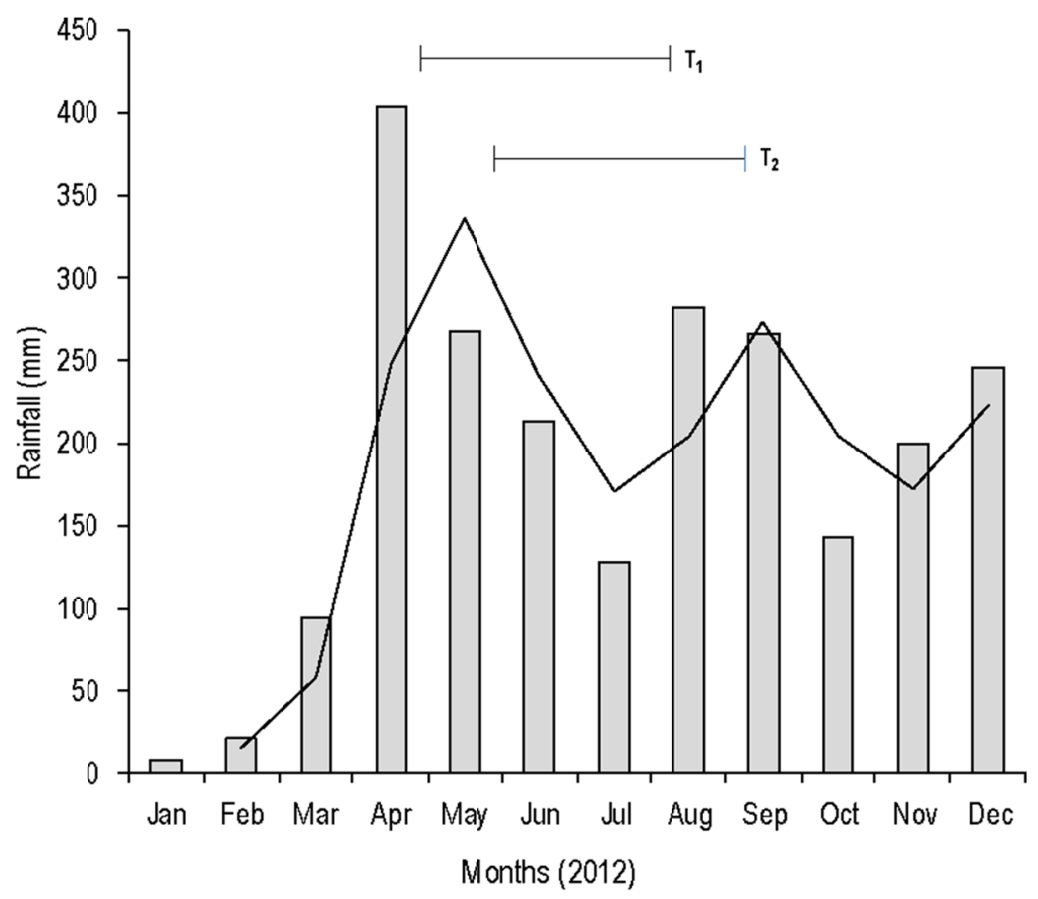

Figure 1. Rainfall in Kakamega county of Western Kenya in the year 2012 during the first field trial (T 1) between $20^{\text {th }}$ April to $30^{\text {th }}$ July 2012, and the second field trial (T 2) between $30^{\text {th }}$ May and $31^{\text {st }}$ August 2012. Total rainfall during the first trial was $1012 \mathrm{~mm}$ with a 3-month average of $253 \mathrm{~mm}$. Total rainfall during the second trial was $622 \mathrm{~mm}$ with a 3-month average of $207 \mathrm{~mm}$ (Source: Naluyange 2013; Courtesy of the Kenya Agricultural and Livestock Research Organization (KALRO), Kakamega, Kenya)

\subsection{Water Hyacinth Composts}

Two formulations of compost made from water hyacinth + cattle manure culture $(\mathrm{H}+\mathrm{CMC})$ and water hyacinth + effective microbes $(\mathrm{H}+\mathrm{EM})$ were prepared using aboveground closed aerobic heap design (Naluyange et al., 2014). The H+CMC compost formulation was prepared by mixing chopped and dried water hyacinth material with a culture of decomposed cattle manure to supply saprophytic microbes. The H+CMC compost had a density of $58 \mathrm{~g} / 100 \mathrm{~cm}^{3}$, with a nutrient concentration of total phosphorus (375 ppm), total nitrogen $(1.1 \%)$, organic carbon $(13.4 \%)$, potassium $\left(21 \mathrm{cmol}_{\mathrm{c}} \mathrm{kg}^{-1}\right)$, sodium $\left(1.9 \mathrm{cmol}_{\mathrm{c}} \mathrm{kg}^{-1}\right)$, calcium $\left(22.3 \mathrm{cmol}_{\mathrm{c}} \mathrm{kg}^{-1}\right)$, magnesium (12 $\left.\mathrm{cmol}_{\mathrm{c}} \mathrm{kg}^{-1}\right)$, zinc (2 ppm) and iron (1.9 ppm), with alkaline pH of 8.1 (Naluyange et al., 2014).

The H+EM compost formulation was prepared by mixing dried and chopped water hyacinth material with Effective Microorganisms solution (EM ${ }^{\mathrm{TM}}$ ), containing photosynthetic bacteria (Rhodopseudomonas palustris), lactic acid bacteria (Lactobacillus plantarum and L. casei), yeast (Saccharomyces cerevisae), molasses and water (EM Technologies Ltd, Embu, Kenya). The H+EM compost had a density of $62 \mathrm{~g} / 100 \mathrm{~cm}^{3}$, with the nutrient concentration of total phosphorus $(270 \mathrm{ppm})$, total nitrogen $(1 \%)$, organic carbon $(13.5 \%)$, potassium $(24.5$ $\left.\mathrm{cmol}_{\mathrm{c}} \mathrm{kg}^{-1}\right)$, sodium $\left(1.7 \mathrm{cmol}_{\mathrm{c}} \mathrm{kg}^{-1}\right)$, calcium $\left(27.5 \mathrm{cmol}_{\mathrm{c}} \mathrm{kg}^{-1}\right)$, magnesium $\left(15.3 \mathrm{cmol}_{\mathrm{c}} \mathrm{kg}^{-1}\right)$, zinc (4 ppm) and iron (1.7 ppm), with alkaline $\mathrm{pH}$ of 8.4 (Naluyange et al., 2014). 


\subsection{Seed Inoculation and Planting}

Seeds of the local yellow bean cultivar 'Mugasa' were purchased from the Kakamega town market in Western Kenya. These are among uncertified seeds that are widely grown by farmers (Otsyula et al., 2004). The bean seeds were inoculated with Rhizobium inoculant powder as per manufacturer's directions (BIOFIX ${ }^{\circledR}$, MEA Ltd, Kenya). The seeds $(250 \mathrm{~g})$ were mixed in gum Arabic solution ( $0.5 \mathrm{gum}$ Arabic/ $5 \mathrm{~mL}$ of sterile lukewarm water) The gum Arabic-coated seeds $(250 \mathrm{~g})$ were mixed with the Rhizobium inoculant powder $(1 \mathrm{~g})$. Controls were coated with gum Arabic solution only.

Planting holes of $\sim 200 \mathrm{~cm}^{3}$ volume (i.e. $\sim 5 \mathrm{~cm}$ diameter and $\sim 10 \mathrm{~cm}$ deep) were dug using a shovel. The water hyacinth composts were applied using containers of $150 \mathrm{~mL}$ volumes per hole (i.e. $\sim 90 \mathrm{~g}$ ) as per the respective treatments and mixed with soil. Therefore, each planting hole received approximately $0.03 \mathrm{~g}$ phosphorus and $0.99 \mathrm{~g}$ nitrogen for the $\mathrm{H}+\mathrm{CMC}$ compost; or $0.02 \mathrm{~g}$ phosphorus and $0.90 \mathrm{~g}$ nitrogen in case of the $\mathrm{H}+\mathrm{EM}$ compost. For the DAP treatment, one leveled teaspoon $(4.7 \mathrm{~g})$ was mixed with soil in the planting hole (Naluyange et al. 2014). DAP fertilizer contains nitrogen (18\%) and phosphorus pentoxide $\mathrm{P}_{2} \mathrm{O}_{5}(46 \%)$, with phosphorus (P) constituting $20 \%$ of the total mass. Hence, every planting hole in the DAP treatment received $0.94 \mathrm{~g}$ phosphorus and $0.85 \mathrm{~g}$ nitrogen. One bean seed was sown in every planting hole at a depth of $\sim 2 \mathrm{~cm}$.

\subsection{Data Collection}

Data was recorded as described by Naluyange et al. (2014). The emergence date of every seedling was recorded independently, and used to determine the duration for germination. The number of seedlings that germinated out of the total number of seeds that were planted was used to calculate the germination percentage within 20 days from the planting date. When the first trifoliate leaves were fully formed in $\sim 80 \%$ of the seedlings, plant height (stem base to petiole), length of the middle leaf (base to apex) and its width (widest part) were recorded. The date when the first flower of every plant appeared was recorded and used to calculate the duration for flowering. Ten days from the onset of flowering, 5 bean plants were randomly selected from each treatment per block for the estimation of number of root nodules associated with Rhizobium colonization. The bean plants were dug out with their root system still holding rhizosphere soil and transported to the laboratory in plastic bags. Rhizosphere soil from each bean plant was gently removed onto a white paper. Detached root nodules in the soil and those still attached to the roots were carefully quantified using a tally counter. This method maximized the collection and counting of root nodules. At harvest, the pods from every plant were packed in separate paper packets and sun dried for a period of five days; the weight of bean seeds per plant was recorded.

Aphid infestations on bean plants were recorded at the vegetative and flowering stage of bean growth. Three screw-capped vessels each containing $10 \mathrm{~mL}$ of $70 \%$ ethanol were placed on every treatment row of 25 plants. Aphids from every 8 plants per row were collected into each container using a camel hair brush from leaves and stems. The collected aphids were identified under a dissection microscope (Model Z45E, Leica Inc., USA) at $\times$ 10 magnifications using the features described by Martin (1983) and Holman (1998), and their absolute counts recorded using a tally counter. These insects have already been identified as the black bean aphid A. fabae (Naluyange et al., 2014). At the vegetative stage, the bean plants were also scored for incidence of anthracnose disease (C. lindemuthianum) i.e. the proportion of plants having anthracnose symptoms, characterized by dark brown to black lesions on leaves (Hagedorn \& Inglis, 1986; Buruchara et al., 2010).

\subsection{Statistical Analysis}

Statistical analyses were conducted using SAS 9.1 software (SAS Institute Inc.) at $p<0.05$ confidence level. Proc Means was used in the generation of descriptive statistics such as means and standard errors for nodule counts, aphid population, plant growth (duration and size) and yields (pod counts and seed weight). These data were graphically checked for normality using Proc Univariate; while Proc Transreg was used to find appropriate Box-Cox power transformations for normalization of data. Data for aphid population were log-transformed, while untransformed data were used for nodule counts. Frequencies for germination (\%) and anthracnose disease incidence (\%) were generated using Proc Freq. For plant growth and aphid population, Analyses of Variance (ANOVA) between treatment means for the fertility, Rhizobium and trial factors were done by Proc Mixed using the three blocks as random effects and the two trials (or plant growth stage for aphid data) as repeated measures. Means for plant growth and aphid population were separated using Ls-means when treatment effects were significant $(\mathrm{p}<0.05)$. Anthracnose disease incidences and germination percentages were analyzed by Proc Genmod ( $\chi^{2}$ test; binomial) and percentages compared using Proc Multtest. Germination percentage data for the two seasons were combined because they were similar. Percentage increase and decrease in nodulation, aphid populations, plant growth and yields were calculated using the formula:- 


$$
\frac{X i-X c}{X c} \times 100 \%
$$

Whereby $X c=$ mean for untreated controls (Non); and $X i=$ mean for other treatments.

\section{Results and Discussion}

In this study, it was expected that plants treated with water hyacinth composts and Rhizobium inoculant would exhibit improved nodulation, growth and yields, while expressing tolerance to infestations by $A$. fabae and $C$. lindemuthianum. The average number of root nodules in the untreated plants was seven $($ mean $=7)$, but significantly increased in plants grown using the water hyacinth composts without Rhizobium, with $\mathrm{H}+\mathrm{CMC}$ attaining an extra $200 \%$ (i.e. +14 nodules) and H+EM scoring extra $278 \%$ (i.e. +19 nodules), when compared to the untreated controls $\left(\mathrm{df}=7, \chi^{2}=1138, \mathrm{p}<0.0001\right)$ (Figure 2). Because these plants had not been inoculated,

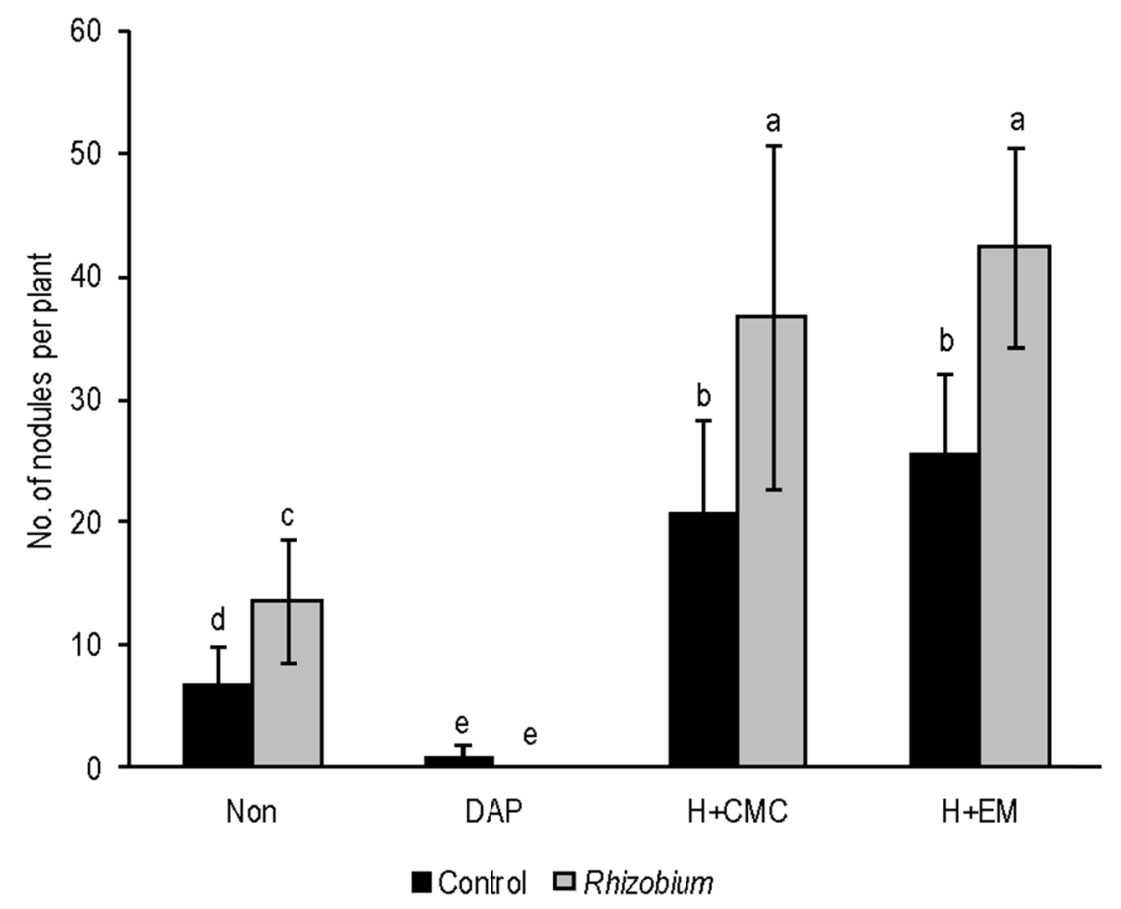

Figure 2. Number of root nodules in local yellow bean plants (var. Mugasa) as affected by commercial Rhizobium inoculant and soil fertility amendments; without fertilizer (Non), diammonium phosphate fertilizer

(DAP), water hyacinth compost + cattle manure culture $(\mathrm{H}+\mathrm{CMC})$ and water hyacinth compost + effective microbes $(\mathrm{H}+\mathrm{EM})$. Bars with the same letter(s) are not significantly different $\left(\chi^{2}\right.$ test, $\left.\mathrm{p}>0.05\right)$

the nodules are likely to have been formed by native strains of Rhizobium species (Dean et al., 2009; Naluyange et al., 2014). The Rhizobium inoculant, which significantly increased nodulation of plants grown without fertilizer by $100 \%$ (i.e. +7 nodules), also performed better in combination with the water hyacinth composts, attaining high increases in nodulation at $440 \%$ (i.e. +30 nodules) for $\mathrm{H}+\mathrm{CMC}$ and $524 \%$ (i.e. +36 nodules) in $\mathrm{H}+\mathrm{EM}$ (Figure 2). These results on root nodulation are in line with the expectations that the water hyacinth composts and Rhizobium inoculant can promote root nodulation in the yellow bean, which indicates their compatibility (Naluyange et al., 2014). Microbes in the two water hyacinth composts may have enhanced root nodulation by Rhizobium, probably through phosphate solubilization (Argaw, 2012; Messele \& Pant, 2012). Bean plants that received DAP had the lowest number of root nodules (Figure 2), despite the fertilizer being rich in phosphorus required for nodulation (Ssali \& Keya, 1983; Graham \& Vance, 2003). Reduction in nodule counts for DAP treatments ranged between $-87 \%$ to $-100 \%$ (i.e. zero nodules). The reduced nodulation has been linked to the chemical composition of inorganic fertilizers that limits the survival of Rhizobia (Peterson \& Kremer, 1989). It is likely that the DAP inhibited Rhizobium nodulation, probably through acidification (Thawornchaisit \& Polprasert, 2009). The soil was also already acidic with a $\mathrm{pH}$ of 4.2. Based on nutrient concentration, it is unlikely that nitrogen in DAP played a significant role in inhibiting root nodulation, because the levels of $\mathrm{N}$ 
supplied to every plant in the three fertility treatments were similar i.e. DAP $(0.85 \mathrm{~g}), \mathrm{H}+\mathrm{CMC}$ compost $(0.99 \mathrm{~g})$ and $\mathrm{H}+\mathrm{CMC}$ compost $(0.90 \mathrm{~g})$. However, the ammonium form of nitrogen in DAP could have inhibited root nodulation and diazotrophic activities of Rhizobium inoculant (Huss-Danell et al., 1982; Mendoza et al., 1995). The form of nitrogen and phosphorus in the two water hyacinth composts was not established (Naluyange et al., 2014).

Composts and other soil fertility amendments can influence seed germination through properties such as water holding capacity (Celik et al., 2004) and chemical activities including phytotoxicity (Hartz et al., 1996; Kabir et al., 2010). Influence of the two water hyacinth composts $(\mathrm{H}+\mathrm{CMC}$ and $\mathrm{H}+\mathrm{EM})$ on seed germination percentage and duration were not evident, as there was no difference with those grown without fertilizer $(\mathrm{p}>0.05)$ (Figure 3). This was also the case in the commercial Rosecoco bean variety (Naluyange et al., 2014). Overall germination percentage for bean seeds in the first trial $(74.8 \%)$ was significantly lower than in the second trial $(81.4 \%)\left(\chi^{2}=6.93 ; p=0.0085\right)$. However, there was no difference in germination percentage between the two trials when the DAP treatment was excluded in the statistical analysis $\left(\mathrm{df}=1, \chi^{2}=0.31, \mathrm{p}=0.58\right)$. Variations in germination percentage between the two trials can be explained by the large difference in germination percentages of seeds grown with DAP, which were $-87 \%$ in the first trial and $-56 \%$ in the second trial. It is likely that the differences in climatic factors such as rainfall (Figure 1), may have affected the efficacy of DAP through soil moisture related processes (Olson \& Dreier, 1956; Hoeft et al., 1975; Hartz et al., 1996; Salvagiotti et al., 2013). Rhizobia are known to improve seed germination by secretion of Nod-factors and phytohormones (Prithiviraj et al., 2003; Cassan et al., 2009). In the current study, there was no indication that the Rhizobium inoculant stimulated seed germination, but the inoculated seeds even exhibited further germination suppression when grown with DAP (Figure 3). This is an issue that requires investigation. Plants grown with DAP took longer period to germinate (Table 1), an effect that has been reported in other studies (Naluyange et al., 2014).

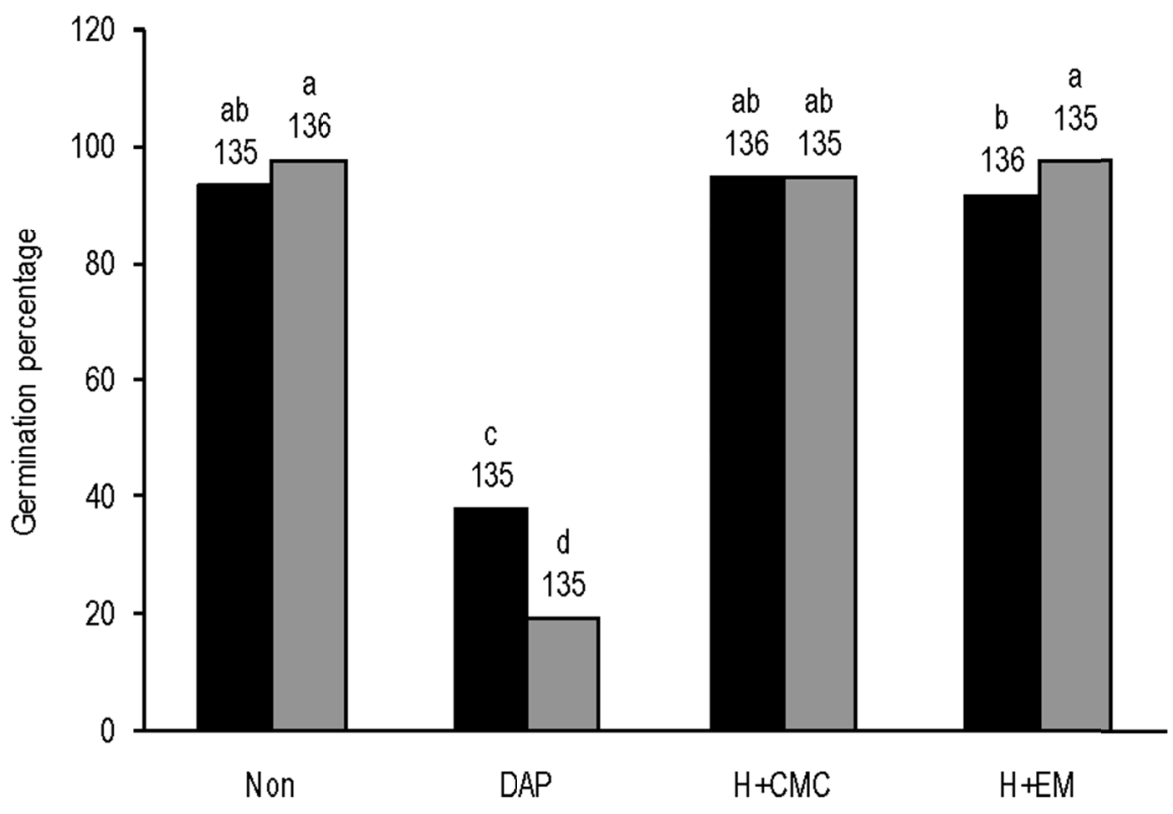

\section{-Control aRhizobium}

Figure 3. Germination percentage of local yellow bean seeds (var. Mugasa) as affected by commercial Rhizobium inoculant and soil fertility amendments; without fertilizer (Non), diammonium phosphate fertilizer

(DAP), water hyacinth compost + cattle manure culture $(\mathrm{H}+\mathrm{CMC})$ and water hyacinth compost + effective microbes $(\mathrm{H}+\mathrm{EM})$. Numbers on top of bars represent sample sizes. Bars with the same letter(s) are not significantly different $\left(\chi^{2}\right.$ test, $\left.p>0.05\right)$

Beans grown with the two types of water hyacinth compost and those without fertilizer were not different in terms of plant size, days to flowering, as well as pod counts and seed weight per plot $(\mathrm{p}>0.05)($ Table 1$)$. Furthermore, Rhizobium-related effects on the previously mentioned parameters were not detected (Table 1). In 
the Rosecoco bean, plants grown with the two water hyacinth composts were large in size, and exhibited improved growth and yields in the second trial (Naluyange et al., 2014). Differences between the yellow bean and the Rosecoco in terms of response towards the two types of compost may be cultivar-related (Naluyange, 2013); although methodological differences such as statistical analysis approach need to be considered in this judgment. Yellow bean plants treated with DAP took the longest time to emerge and flower, while exhibiting reduced yields per unit area in terms of pod count (-64\%) and seed weight (-67\%) (Table 1). The low yields are a result of the low germination percentage in the DAP treatment (Figure 3). Despite reduction in germination percentage, individual mature plants from DAP treatments become large in size indicating that inhibitive effects of DAP are temporary (Naluyange et al., 2014). Such negative effects of DAP may be due to edaphic and climatic conditions specific to study locations (Ghizaw et al., 1999), because DAP has been reported to enhance bean yields in many other regions around the world (Zhang et al., 2008; Zafar et al., 2013). Bean plants in the first trial took shorter time to flower, were taller and produced higher number of pods with greater seed weight per unit area compared to the second trial (Table 1). The primary reason for this observation is the relatively more rainfall during the first trial $(1012 \mathrm{~mm})$ than in the second trial $(622 \mathrm{~mm})$ in which the relatively young bean plants were exposed to rain shortages in the month of July 2012 (Figure 1).

Table 1. Plant growth and yields of the local yellow bean 'Mugasa' as influenced by Rhizobium inoculant, water hyacinth compost containing cattle manure culture $(\mathrm{H}+\mathrm{CMC})$ or effective microbes $(\mathrm{H}+\mathrm{EM})$ and diammonium phosphate (DAP) fertilizer under field conditions in Western Kenya

\begin{tabular}{|c|c|c|c|c|c|c|c|c|}
\hline & & \multicolumn{7}{|c|}{ Means of means } \\
\hline & & $\begin{array}{l}\text { Emergence } \\
\text { days }\end{array}$ & $\begin{array}{l}\text { Flowering } \\
\text { days }\end{array}$ & $\begin{array}{l}\text { Leaf length } \\
(\mathrm{cm})\end{array}$ & $\begin{array}{l}\text { Leaf width } \\
(\mathrm{cm})\end{array}$ & $\begin{array}{l}\text { Plant height } \\
(\mathrm{cm})\end{array}$ & $\begin{array}{l}\text { Pods } \\
\text { (counts) }\end{array}$ & Yield (g) \\
\hline Overall mean & & $6.90 \pm 0.24$ & $40.32 \pm 0.46$ & $8.37 \pm 0.32$ & $5.44 \pm 0.18$ & $5.16 \pm 0.12$ & $125.29 \pm 12.58$ & $125.2 \pm 13.06$ \\
\hline First trial & & $6.87 \pm 0.14 \mathrm{a}$ & $37.89 \pm 0.28 b$ & $8.49 \pm 0.23 \mathrm{a}$ & $5.76 \pm 0.12 \mathrm{a}$ & $5.72 \pm 0.16 \mathrm{a}$ & $214.98 \pm 16.4 \mathrm{a}$ & $236.66 \pm 13.5 \mathrm{a}$ \\
\hline Second trial & & $6.81 \pm 0.10 \mathrm{a}$ & $42.19 \pm 0.65 \mathrm{a}$ & $8.28 \pm 0.76 \mathrm{a}$ & $5.22 \pm 0.47 \mathrm{a}$ & $4.72 \pm 0.05 \mathrm{~b}$ & $46.29 \pm 6.0 \mathrm{~b}$ & $25.7 \pm 1.34 \mathrm{~b}$ \\
\hline \multirow[t]{4}{*}{ Fertilizer } & Non & $6.55 \pm 0.07 \mathrm{~b}$ & $39.86 \pm 0.35 \mathrm{~b}$ & $8.0 \pm 0.27 \mathrm{a}$ & $5.17 \pm 0.16 \mathrm{a}$ & $4.95 \pm 0.18 \mathrm{~b}$ & $132 \pm 12.12 \mathrm{a}$ & $136.41 \pm 14.75 \mathrm{a}$ \\
\hline & DAP & $8.66 \pm 0.37 \mathrm{a}$ & $43.36 \pm 0.99 \mathrm{a}$ & $7.39 \pm 1.11 \mathrm{a}$ & $4.89 \pm 0.59 \mathrm{a}$ & $4.72 \pm 0.28 \mathrm{~b}$ & $47.17 \pm 26.12 b$ & $45.63 \pm 28.68 b$ \\
\hline & $\mathrm{H}+\mathrm{CMC}$ & $6.26 \pm 0.17 \mathrm{~b}$ & $38.88 \pm 0.35 \mathrm{~b}$ & $9.28 \pm 0.21 \mathrm{a}$ & $6.04 \pm 0.13 \mathrm{a}$ & $5.72 \pm 0.17 \mathrm{a}$ & $175.17 \pm 14.56 \mathrm{a}$ & $167.94 \pm 15.82 \mathrm{a}$ \\
\hline & $\mathrm{H}+\mathrm{EM}$ & $6.15 \pm 0.13 \mathrm{~b}$ & $39.18 \pm 0.25 \mathrm{~b}$ & $8.8 \pm 0.25 \mathrm{a}$ & $5.68 \pm 0.19 \mathrm{a}$ & $5.24 \pm 0.06 \mathrm{ab}$ & $146.83 \pm 7.18 \mathrm{a}$ & $150.85 \pm 7.83 \mathrm{a}$ \\
\hline \multirow[t]{2}{*}{ Inoculum } & Control & $6.86 \pm 0.37 \mathrm{a}$ & $39.98 \pm 0.49 \mathrm{a}$ & $8.17 \pm 0.41 \mathrm{a}$ & $5.34 \pm 0.24 \mathrm{a}$ & $5.23 \pm 0.18 \mathrm{a}$ & $113.75 \pm 15.19 \mathrm{a}$ & $112.13 \pm 16.12 \mathrm{a}$ \\
\hline & Rhizobium & $6.95 \pm 0.31 \mathrm{a}$ & $40.66 \pm 0.78 \mathrm{a}$ & $8.56 \pm 0.49 \mathrm{a}$ & $5.55 \pm 0.27 \mathrm{a}$ & $5.09 \pm 0.16 \mathrm{a}$ & $136.83 \pm 20.18 \mathrm{a}$ & $138.28 \pm 20.56 \mathrm{a}$ \\
\hline $\begin{array}{l}\text { Source of } \\
\text { variation }\end{array}$ & df & $\mathrm{F}$ values & & & & & & \\
\hline Trial & 1,4 & 1.78 & $41.82 * *$ & 0.07 & 1.25 & $30.03 * *$ & $93.16^{* * *}$ & $836^{* * *}$ \\
\hline Fertilizer & 3,16 & $28.58 * * *$ & $19.21 * * *$ & 1.52 & 2.06 & $3.93 *$ & $10.56 * * *$ & $33.57 * * *$ \\
\hline Inoculum & 1,16 & 0.82 & 1.85 & 0.39 & 0.33 & 0.29 & 1.86 & 1.27 \\
\hline $\begin{array}{l}\text { Fertilizer } \times \\
\text { Inoculum }\end{array}$ & 3,16 & 0.82 & 1.68 & 0.17 & 0.04 & 0.12 & 0.39 & 0.27 \\
\hline
\end{tabular}

Populations of the black bean aphid A. fabae were generally low i.e. fewer than 1-2 aphids per plant in most treatments. Aphis fabae population was significantly higher in Rhizobium inoculated plants grown with hyacinth + effective microbes $(\mathrm{H}+\mathrm{EM})$ than the other treatments $\left(\mathrm{F}_{7,37} ; \mathrm{p}=0.0036\right)$ (Figure 4). This increase in $A$. fabae population by $\sim 230 \%$ may be linked activities of the Rhizobium inoculant, although microbes contained in the compost (H+EM) may have also contributed, as this effect was not evident in the other compost $(\mathrm{H}+\mathrm{CMC})$. It also implies that host-mediated effects of Rhizobium on aphids depend on the composition of microbial communities the legume symbiont interacts with in the rhizosphere (Whipps, 2001; Bais et al., 2006; Raaijmakers et al., 2009); as microbial communities that exist in cattle manure culture (Chachkhiani et al., 2004; Maeda et al., 2010), are unlikely to be similar to those in Effective Microbes ${ }^{\circledR}$ (Naluyange et al., 2014). Increase in aphid populations due to Rhizobium inoculation has also been reported in soybean and in the commercial Rosecoco bean (Dean et al., 2009; Naluyange et al., 2014). Since Rhizobium fixes nitrogen in legumes, then 
increased A. fabae density may be linked to high organic nitrogen content that determines nutritive suitability of host plants (Mattson, 1980; Dean et al., 2009; Ballhorn et al., 2013). It is also possible that Rhizobium inoculated plants emit more attractive volatiles to $A$. fabae, a suggestion that requires investigation. However, in the Lima bean Phaseolus lunatus, the application of Rhizobium minimized olfactory attraction of the Mexican bean beetle (Epilachna varivestis) towards plants induced to produce attractive volatiles using jasmonic acid (Ballhorn et al., 2013). The A. fabae population did not vary between the vegetative and flowering stages of bean growth $\left(\mathrm{F}_{1,37} ; \mathrm{p}\right.$ $=0.33$ ).

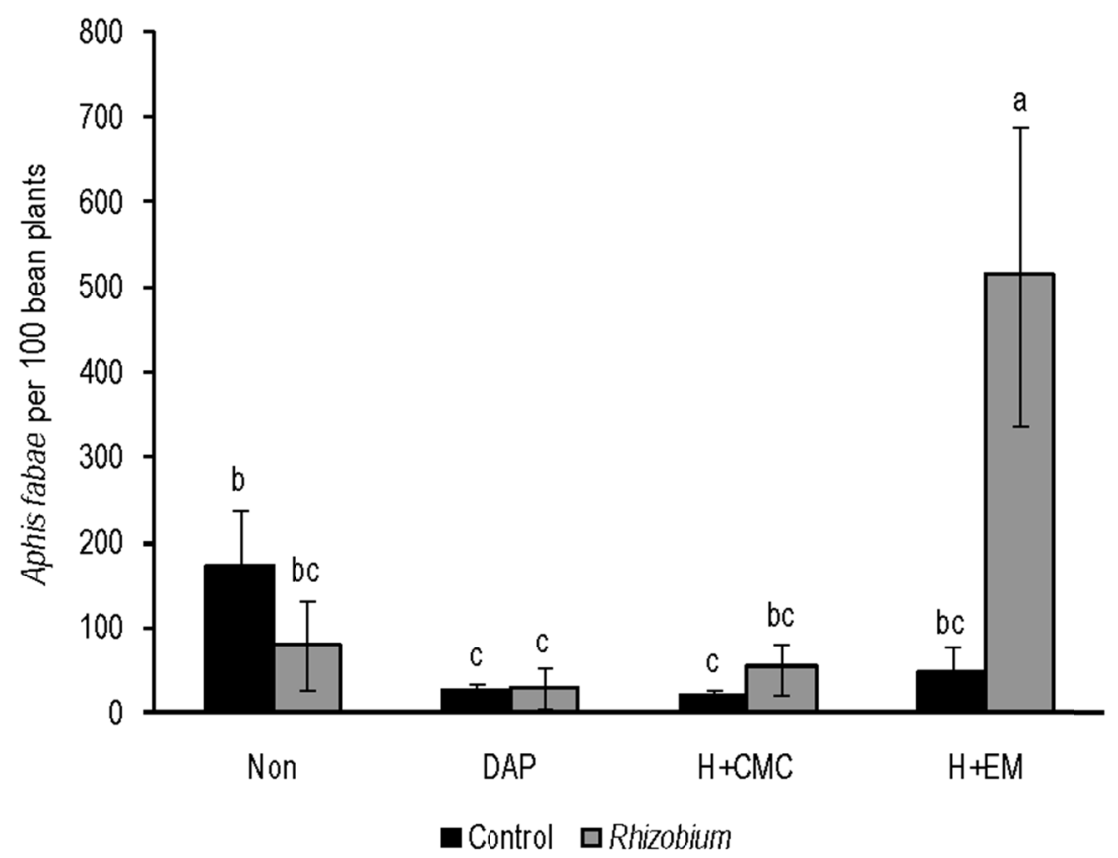

Figure 4. Population of Aphis fabae on local yellow bean plants (var. Mugasa) as affected by commercial Rhizobium inoculant and soil fertility amendments; without fertilizer (Non), diammonium phosphate fertilizer

(DAP), water hyacinth compost + cattle manure culture $(\mathrm{H}+\mathrm{CMC})$ and water hyacinth compost + effective microbes $(\mathrm{H}+\mathrm{EM})$. Bars with the same letter(s) are not significantly different ( $\mathrm{F}$ test, $\mathrm{p}>0.05)$

Incidence of anthracnose disease caused by $C$. lindemuthianum was significantly higher in Rhizobium-inoculated plants than in the non-inoculated plants, particularly in the first trial (Figure 5). It is likely that $C$. lindemuthianum infestations are dependent on Rhizobium activities, which can be supported by the similarity of trends in root nodule counts (Figure 2) and anthracnose incidence across fertility treatments (Figure 5). Just like A. fabae, this effect can also be linked to enhanced nitrogen content due to $\mathrm{N}_{2}$ fixation. This is because Colletotrichum species that cause anthracnose disease and many other phytopathogens have high affinity for nitrogen in host plants (Nam et al., 2006; Tavernier et al., 2007; Lobato et al., 2009; Ochieno, 2010). On average, anthracnose incidence in the first trial $(\sim 62 \%)$ was higher than in the second trial $(\sim 7 \%)$. This is because the first trial had more rainfall (Figure 1), which favours C. lindemuthianum infestations on beans that are more prevalent under moist conditions (Kumar et al., 1999).

Apart from symbiotic nitrogen fixation, there could be other tripartite host-mediated interactions between Rhizobium species, the black bean aphid A. fabae and the anthracnose pathogen $C$. lindemuthianum that need to be established (Stout et al., 2006). First, feeding by aphids induces Rhizobium nodulation in leguminous roots (Heath \& Lau, 2011). This is because the number of root nodules was higher in plants that had high $A$. fabae population, particularly in the $\mathrm{H}+\mathrm{EM}$ compost; which is reverse of the assumption that Rhizobium is the one that causes increase in aphid infestation (Dean et al., 2009; Naluyange et al., 2014). This also contradicts scenarios in which Rhizobium reduces aphid population on crops through induced plant resistance (El-Wakeil \& El-Sebai, 2009; Martinuz et al., 2012). Rhizobium may actually suppress plant immunity instead of boosting induced resistance (Mithofer, 2002; Luo \& Lu, 2014). Secondly, feeding wounds inflicted by $A$. fabae stylets may have facilitated the entry of Colletotrichum hyphae into plant tissues. Since Rhizobium inoculated plants had more $A$. fabae and hence higher number of stylet wounds, then more Colletotrichum hyphae may have penetrated 


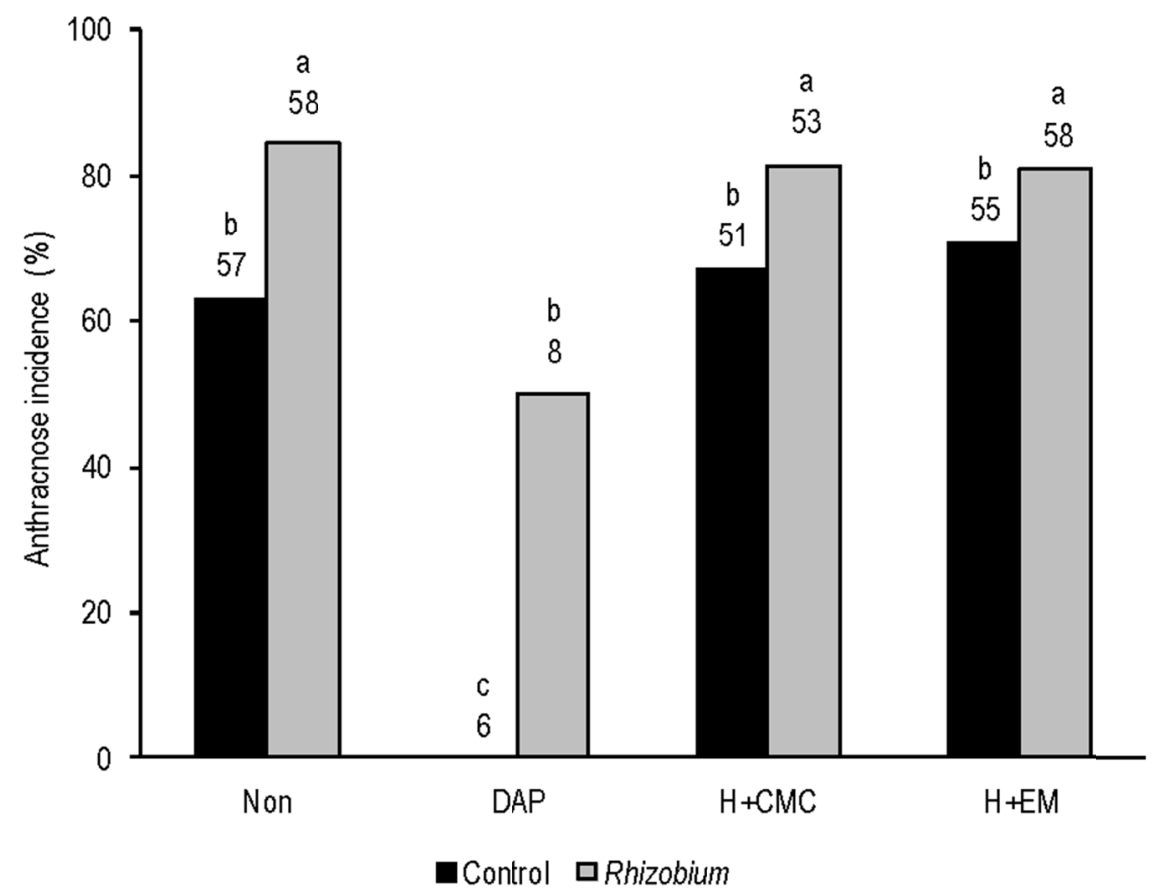

Figure 5. Anthracnose incidences in local yellow bean plants (var. Mugasa) as affected by commercial Rhizobium inoculant and soil fertility amendments; without fertilizer (Non), diammonium phosphate fertilizer

(DAP), water hyacinth compost + cattle manure culture $(\mathrm{H}+\mathrm{CMC})$ and water hyacinth compost + effective microbes $(\mathrm{H}+\mathrm{EM})$. Numbers on top of bars represent sample sizes. Bars with the same letter(s) are not significantly different $\left(\chi^{2}\right.$ test, $\left.p>0.05\right)$

resulting in high anthracnose incidence. However, aphid stylet wounds are too small to permit the entry of fungal pathogens into plant tissues (Mitchell, 2004; Will \& van Bell, 2006). Also, there are reports indicating that feeding by some aphid species inhibits plant tissue colonization by Colletotrichum species (Russo et al., 1997; Stout et al., 2006). Third, high number of aphids on Rhizobium inoculated plants may have secreted vast amounts of honeydew, which may have facilitated saprophytic colonization of bean surfaces by Colletotrichum hyphae prior to pathogenic penetration. However, this scenario is quite unlikely considering the low number of aphids (1-2) per plant. Fourth, both the aphid and the fungal pathogen may have compromised the immune system of the host plant to enhance their colonization (Stout et al., 2006). However, this interpretation may not fully stand, because plants have separate defense mechanisms against Colletotrichum and insect pests (Ajlan \& Potter, 1991). Finally, plant infection by Colletotrichum may have influenced the production of aphid-attracting volatile organic compounds, because some endophytic fungi influence the production of insect attractive compounds (Cardoza et al., 2003; Jallow et al., 2008). However, this cannot be generalized, because Colletotrichum exhibits both biotrophic and necrotrophic infection phases (Bhadauria et al., 2011), which are associated with increase or decrease in A. fabae infestations on beans, respectively (Al-Naemi \& Hatcher, 2013). Relationships between Rhizobium, Colletotrichum and aphids require further investigation.

Despite the high infestations by $A$. fabae and C. lindemuthianum in Rhizobium-inoculated plants grown with water hyacinth compost $(\mathrm{H}+\mathrm{EM})$, the growth and yields were not negatively affected, while the desirable root nodulation was enhanced. This indicates that the plants were tolerant to the insect pest $A$. fabae and the fungal pathogen C. lindemuthianum (Naluyange et al., 2014); although there are possibilities that plant growth promoting benefits of Rhizobium were cancelled by costs towards plant defensive mechanisms (Thaler et al., 1999; Heil et al., 2000).

In conclusion, the water hyacinth composts contain beneficial microbes that promote root nodulation by Rhizobium, which is necessary for nitrogen fixation, while enhancing tolerance to aboveground infestations by $A$. fabae and C. lindemuthianum. We raise questions on our results to stimulate research, considering that bean breeding programs in Africa have mainly focused on microbial pathogens, and not insect pests.

\section{Acknowledgements}

This work was conducted under the sponsorship of the Lake Victoria Research (VicRes) Initiative, a regional 
collaborative research programme of the Inter-University Council for East Africa (IUCEA). Research funds were provided by the Government of Sweden through the Swedish International Development Cooperation Agency (Sida), under the framework of the Lake Victoria Development Partnership (LVDP) Programme.

\section{References}

Ajlan, A. M., \& Potter, D. A. (1991). Does immunization of cucumber against anthracnose by Colletotrichum lagenarium affect host suitability for arthropods? Entomologia Experimentalis et Applicata, 58, 83-91. http://dx.doi.org/10.1111/j.1570-7458.1991.tb01455.x

Al-Naemi, F., \& Hatcher, P. E. (2013). Contrasting effects of necrotrophic and biotrophic plant pathogens on the aphid Aphis fabae. Entomologia Experimentalis et Applicata, 148, 234-245. http://dx.doi.org/10.1111/eea.12091

Argaw, A. (2011) Evaluation of co-inoculation of Bradyrhizobium japonicum and phosphate solubilizing Pseudomonas spp. effect on soybean (Glycine max L. Merr.) in Assossa Area. Journal of Agricultural Science and Technology, 14, 213-224.

Ayuke, F. O., Brussaard, L., Vanlauwe, B., Six, J., Lelei, D. K., Kibunja, C. N., \& Pulleman, M. M. (2011). Soil fertility management: Impacts on soil macrofauna, soil aggregation and soil organic matter allocation. Applied Soil Ecology, 48, 53-62. http://dx.doi.org/10.1016/j.apsoil.2011.02.001

Bais, H. P., Weir, T. L., Perry, L. G., Gilroy, S., \& Vivanco, J. M. (2006). The role of root exudates in rhizosphere interactions with plants and other organisms. Annual Review of Plant Biology, 57, 233-266. http://dx.doi.org/10.1146/annurev.arplant.57.032905.105159

Bala, A., Karanja, N., Murwira, M., Lwimbi, L., Abaidoo, R., \& Giller, K. (2011). Production and use of Rhizobial inoculants in Africa. Retrieved from www.N2Africa.org

Ballhorn, D. J., Kautz, S., \& Schadler, M. (2013). Induced plant defense via volatile production is dependent on rhizobial symbiosis. Oecologia, 172, 833-846. http://dx.doi.org/10.1007/s00442-012-2539-x

Beebe, S. (2012). Common bean breeding in the Tropics. In J. Janick (Ed.), Plant Breeding Reviews (Vol. 36, pp 357-426). John Wiley \& Sons, Inc., Hoboken, NJ, USA. http://dx.doi.org/10.1002/9781118358566.ch5

Bhadauria, V., Banniza, S., Vandenberg, A., Selvaraj, G., \& Wei, Y. (2011). EST mining identifies proteins putatively secreted by the anthracnose pathogen Colletotrichum truncatum. BMC Genomics, 12, 327. http://dx.doi.org/10.1186/1471-2164-12-327

Buruchara, R., Mukankusi, C., \& Ampofo, K. (2010). Bean Disease and Pest Identification and Management: Handbooks for small-scale seed producers no.04. International Center for Tropical Agriculture (CIAT); Pan-Africa Bean Research Alliance (PABRA).

Cardoza, Y. J., Teal, P. E. A., \& Tumlinson, J. H. (2003). Effect of peanut plant fungal infection on oviposition preference by Spodoptera exigua and on host-searching behavior by Cotesia marginiventris. Environmental Entomology, 32, 970-976. http://dx.doi.org/10.1603/0046-225X-32.5.970

Cassan, F., Perrig, D., Sgroya, V., Masciarellia, O., Penna, C., \& Luna, V. (2009). Azospirillum brasilense Az39 and Bradyrhizobium japonicum E109, inoculated singly or in combination, promote seed germination and early seedling growth in corn (Zea mays L.) and soybean (Glycine max L.). European Journal of Soil Biology, 45, 28-35. http://dx.doi.org/10.1016/j.ejsobi.2008.08.005

Celik, I., Ortas, I., \& Kilic, S. (2004). Effects of compost, mycorrhiza, manure and fertilizer on some physical properties of a Chromoxerert soil. Soil and Tillage Research, 78, 59-67. http://dx.doi.org/10.1016/j.still.2004.02.012

Chachkhiani, M., Dabert, P., Abzianidze, T., Partskhaladze, G., Tsiklauri, L., Dudauri, T., \& Godon, J. J. (2004). $16 \mathrm{~S}$ rDNA characterisation of bacterial and archaeal communities during start-up of anaerobic thermophilic digestion of cattle manure. Bioresource Technology, 93, 227-232. http://dx.doi.org/10.1016/j.biortech.2003.11.005

Danielsen, S., Boa, E., Mafabi, M., Mutebi, E., Reeder, R., Kabeere, F., \& Karyeija, R. (2013). Using plant clinic registers to assess the quality of diagnoses and advice given to farmers: a case study from Uganda. The Journal of Agricultural Education and Extension, 19, 183-201. http://dx.doi.org/10.1080/1389224X.2012.741528

David, S., \& Sperling, L. (1999). Improving technology delivery mechanisms: lessons from bean seed systems in eastern and central Africa. Agriculture and Human Values, 16, 381-388. 
http://dx.doi.org/10.1023/A:1007603902380

de Graaff, J., Kessler, A., \& Nibbering, J. W. (2011). Agriculture and food security in selected countries in Sub-Saharan Africa: diversity in trends and opportunities. Food Security, 3, 195-213. http://dx.doi.org/10.1007/s12571-011-0125-4

Dean, J. M., Mescher, M. C., \& de Moraes, C. M. (2009). Plant-rhizobia mutualism influences aphid abundance on soybean. Plant and Soil, 323, 187-196. http://dx.doi.org/10.1007/s11104-009-9924-1

Dean, J. M., Mescher, M. C., \& de Moraes, C. M. (2014). Plant dependence on Rhizobia for nitrogen influences induced plant defenses and herbivore performance. International Journal of Molecular Sciences, 15, 1466-1480. http://dx.doi.org/10.3390/ijms15011466

Devi, M. J., Sinclair, T. R., Beebe, S. E., \& Rao, I. M. (2013). Comparison of common bean (Phaseolus vulgaris L.) genotypes for nitrogen fixation tolerance to soil drying. Plant and Soil, 364, 29-37. http://dx.doi.org/10.1007/s11104-012-1330-4

El-Wakeil, N. E., \& El-Sebai, T. N. (2009). Role of biofertilizer on faba bean growth, yield, and its effect on bean aphid and the associated predators. Archives of Phytopathology and Plant Protection, 42, 1144-1153. http://dx.doi.org/10.1080/03235400701650882

FAO. (1947). Soil Map of the World 1: 5,000, 000 (vol. 1, p. 72). Legend, FAO/UNESCO.

Ghizaw, A., Mamo, T., Yilma, Z., Molla, A., \& Ashagre, Y. (1999). Nitrogen and phosphorus effects on faba bean yield and some yield components. Journal of Agronomy and Crop Science, 182, 167-174. http://dx.doi.org/10.1046/j.1439-037x.1999.00272.x

Graham, P. H., \& Vance, C. P. (2003). Legumes: importance and constraints to greater use. Plant Physiology, 131, 872-877. http://dx.doi.org/10.1104/pp.017004

Graham, P. H., \& Vance, C. P. (2000). Nitrogen fixation in perspective: an overview of research and extension needs. Field Crops Research, 65, 93-106. http://dx.doi.org/10.1016/S0378-4290(99)00080-5

Gunnarsson, C. C., \& Petersen, C. M. (2007). Water hyacinths as a resource in agriculture and energy production: A literature review. Waste Management, 27, 117-129. http://dx.doi.org/10.1016/j.wasman.2005.12.011

Hagedorn, D. J., \& Inglis, D. A. (1986). Handbook of Bean Diseases (p. 24). University Wisconsin-Madison Extension Bulletin A3374.

Hartz, T. K., Costa, F. J., \& Schrader, W. L. (1996). Suitability of composted green waste for horticultural uses. HortScience, 31, 961-964.

Heath, K. D., \& Lau, J. A. (2011). Herbivores alter the fitness benefits of a plant-Rhizobium mutualism. Acta Oecologica, 37, 87-92. http://dx.doi.org/10.1016/j.actao.2010.12.002

Hecky, R. E., Mugidde, R., Ramlal, P. S., Talbot, M. R., \& Kling, G. W. (2010). Multiple stressors cause rapid ecosystem change in Lake Victoria. Freshwater Biology, 55, 19-42. http://dx.doi.org/10.1111/j.1365-2427.2009.02374.x

Heil, M., Hilpert, A., Kaiser, W., \& Linsenmair, K. E. (2000). Reduced growth and seed set following chemical induction of pathogen defence: does systemic acquired resistance (SAR) incur allocation costs? Journal of Chemical Ecology, 88, 645-654. http://dx.doi.org/10.1046/j.1365-2745.2000.00479.x

Hoeft, R. G., Walsh, L. M., \& Liegel, E. A. (1975). Effect of seed-placed fertilizer on the emergence (germination) of soybeans (Glycine max L.) and snapbeans (Phaseolus vulgaris L.). Communications in Soil Science and Plant Analysis, 6, 655-664. http://dx.doi.org/10.1080/00103627509366601

Holman, J. (1998). Species of the genus Aphis (Sternorrhyncha: Aphidoidea) living on Hieracium (Asteraceae: Cichorieae). European Journal of Entomology, 95, 383-394.

Huss-Danell, K., Sellstedt, A., Flower-Ellis, A., \& Sjöström, M. (1982). Ammonium effects on function and structure of nitrogen-fixing root nodules of Alnus incana (L.) Moench. Planta, 156, 332-340. http://dx.doi.org/10.1007/BF00397471

Israel, D. W. (1987). Investigation of the role of phosphorus in symbiotic dinitrogen fixation. Plant Physiology, 84, 835-840. http://dx.doi.org/10.1104/pp.84.3.835

Jakobsen, I. (1985). The role of phosphorus in nitrogen fixation by young pea plants (Pisum sativum). Physiologia Plantarum, 64, 190-196. http://dx.doi.org/10.1111/j.1399-3054.1985.tb02334.x 
Jallow, M. F. A., Dugassa-Gobena, D., \& Vidal, S. (2008). Influence of an endophytic fungus on host plant selection by a polyphagous moth via volatile spectrum changes. Arthropod-Plant Interactions, 2, 53-62. http://dx.doi.org/10.1007/s11829-008-9033-8

Kabir, E., Bell, R. W., \& Johansen, C. (2010). Triple superphosphate placement affects early growth of chickpea. In 19th World Congress of Soil Science, Soil Solutions for a Changing World, Brisbane, Australia (pp. 276-279).

Katayama, N., Nishida, T., Zhang, Z. Q., \& Ohgushi, T. (2010). Belowground microbial symbiont enhances plant susceptibility to a spider mite through change in soybean leaf quality. Population Ecology, 52, 499-506. http://dx.doi.org/10.1007/s10144-010-0207-8

Katayama, N., Zhang, Z. Q., \& Ohgushi, T. (2011). Community-wide effects of below-ground rhizobia on $\begin{array}{lllll}\text { above-ground } & \text { arthropods. } & \text { Ecological } & \text { Entomology, } & 36,\end{array}$ http://dx.doi.org/10.1111/j.1365-2311.2010.01242.x

Kempel, A., Brandl, R., \& Schadler, M. (2009). Symbiotic soil microorganisms as players in aboveground plant-herbivore interactions-the role of Rhizobia. Oikos, 118, 634-640. http://dx.doi.org/10.1111/j.1600-0706.2009.17418.x

Kharinda, B. T. M. (2013). Phenotypic characterization of common bean genotypes for resistance to the pathogen Colletotrichum lindemuthianum constraining bean production in western Kenya. MSc. Thesis, Masinde Muliro University of Science and Technology, Kakamega, Kenya.

Kihara, J., Vanlauwe, B., Waswa, B., Kimetu, J. M., Chianu, J., \& Bationo, A. (2010). Strategic phosphorus application in legume-cereal rotations increases land productivity and profitability in Western Kenya. Experimental Agriculture, 46, 35-52. http://dx.doi.org/10.1017/S0014479709990810

Kimani, J. M., Kimani, P. M., Githiri, S. M., \& Kimenju, J. W. (2007). Mode of inheritance of common bean (Phaseolus vulgaris L.) traits for tolerance to low soil phosphorus (P). Euphytica, 155, 225-234. http://dx.doi.org/10.1007/s10681-006-9324-z

Kimani, J. M., \& Tongoona, P. (2008). The mechanism of genetic control for low soil nitrogen (N) tolerance in common beans (Phaseolus vulgaris L.). Euphytica, 162, 193-203. http://dx.doi.org/10.1007/s10681-007-9499-y

Kumar, A., Sharma, P. N., Sharma, O. P., \& Tyagi, P. D. (1999). Epidemiology of bean anthracnose Colletotrichum lindemuthianum under sub-humid mid-hills zone of Himachal Pradesh. Indian Phytopathology, 52, 393-397.

Lobato, A. K. S., Gonçalves-Vidigal, M. C., Vidigal-Filho, P. S., Costa, R. C. L, Lopes, M. J. S., Cruz, A. S., ... Gonçalves, A. M. O. (2009). Nitrogen compounds responses in two cultivars of common bean inoculated with Colletotrichum lindemuthianum. Research Journal of Biological Sciences, 4, 293-297.

Lung'ayia, H., Sitoki, L., \& Kenyanya, M. (2001). The nutrient enrichment of Lake Victoria (Kenyan waters). Hydrobiologia, 458, 75-82. http://dx.doi.org/10.1023/A:1013128027773

Maeda, K., Hanajima, D., Morioka, R., \& Osada, T. (2010). Characterization and spatial distribution of bacterial communities within passively aerated cattle manure composting piles. Bioresource Technology, 101, 9631-9637. http://dx.doi.org/10.1016/j.biortech.2010.07.057

Martin, J. H. (1983). The identification of common aphid pests of tropical agriculture. Tropical Pest Management, 29, 395-411. http://dx.doi.org/10.1080/09670878309370834

Martinuz, A., Schouten, A., Menjivar, R. D., \& Sikora, R. A. (2012). Effectiveness of systemic resistance toward Aphis gossypii (Hom., Aphididae) as induced by combined applications of the endophytes Fusarium oxysporum Fo162 and Rhizobium etli G12. Biological Control, 62, 206-212. http://dx.doi.org/10.1016/j.biocontrol.2012.05.006

Mattson, W. J. (1980). Herbivory in relation to plant nitrogen content. Annual Review of Ecology and Systematics, 11, 119-161. http://dx.doi.org/10.1146/annurev.es.11.110180.001003

Mauyo, L. W., Okalebo, J. R., Kirkby, R. A., Buruchara, R., Ugen, M., \& Maritim, H. K. (2007). Spatial pricing efficiency and regional market integration of cross-border bean (Phaseolus Vulgaris L.) marketing in East Africa: The case of Western Kenya and Eastern Uganda. In A. Bationo, B. Waswa, J. Kihara \& J. Kimetu (Eds.), Advances in Integrated Soil Fertility Management in sub-Saharan Africa: Challenges and Opportunities (pp. 1027-1034). Springer, Netherlands. http://dx.doi.org/10.1007/978-1-4020-5760-1_100 
Mendoza, A., Leija, A., Martínez-Romero, E., Hernández, G., \& Mora, J. (1995). The enhancement of ammonium assimilation in Rhizobium elti prevents nodulation of Phaseolus vulgaris. Molecular Plant-Microbe Interactions, 8, 584-592. http://dx.doi.org/10.1094/MPMI-8-0584

Messele, B., \& Pant, L.M. (2012). Effects of inoculation of Sinorhizobium ciceri and phosphate solubilizing bacteria on nodulation, yield and nitrogen and phosphorus uptake of Chickpea (Cicer arietinum L.) in Shoa $\begin{array}{lllllll}\text { Robit Area. Journal of Biofertilizers \& } & \text { Biopesticides, } & 3, & 129 .\end{array}$ http://dx.doi.org/10.4172/2155-6202.10000129

Mireri, C., Atekyereza, P., Kyessi, A., \& Mushi, N. (2007). Environmental risks of urban agriculture in the Lake Victoria drainage basin: A case of Kisumu municipality, Kenya. Habitat International, 31, 375-386. http://dx.doi.org/10.1016/j.habitatint.2007.06.006

Mitchell, P. L. (2004). Heteroptera as vectors of plant pathogens. Neotropical Entomology, 33, 519-545. http://dx.doi.org/10.1590/S1519-566X2004000500001

Mohamed, H. M., \& Abdel-Moniem, A. (2010). Evaluation of water hyacinth and sugarcane bagasse composts as a carrier for Rhizobium inoculants and their effects on faba bean. Research Journal of Agriculture and Biological Sciences, 6, 1022-1028.

Naluyange, V. (2013). Compatibility of Rhizobium inoculant with water hyacinth manure formulations in common bean and consequences on Aphis fabae and Colletotrichum lindemuthianum infestations. MSc. Thesis, Masinde Muliro University of Science and Technology, Kakamega, Kenya.

Naluyange, V., Ochieno, D. M. W., Maingi, J. M., Ombori, O., Mukaminega, D., Amoding, A., ... Muoma, J. V. O. (2014). Compatibility of Rhizobium inoculant and water hyacinth compost formulations in Rosecoco bean and consequences on Aphis fabae and Colletotrichum lindemuthianum infestations. Applied Soil Ecology, 76, 68-77. http://dx.doi.org/10.1016/j.apsoil.2013.12.011

Nam, M. H., Jeong, S. K., Lee, Y. S., Choi, J. M., \& Kim, H. G. (2006). Effects of nitrogen, phosphorus, potassium and calcium nutrition on strawberry anthracnose. Plant Pathology, 55, 246-249. http://dx.doi.org/10.1111/j.1365-3059.2006.01322.x

Ntiba, M. J., Kudoja, W. M., \& Mukasa, C. T. (2001). Management issues in the Lake Victoria watershed. Lakes and Reservoirs Research and Management, 6, 211-216. http://dx.doi.org/10.1046/j.1440-1770.2001.00149.x

Nunan, F. (2013). Wealth and welfare? Can fisheries management succeed in achieving multiple objectives? A case study of Lake Victoria, East Africa. Fish and Fisheries. http://dx.doi.org/10.1111/faf.12012

Ochieno, D. M. W. (2010). Endophytic control of Cosmopolites sordidus and Radopholus similis using Fusarium oxysporum V5w2 in tissue culture banana. Doctoral thesis and Propositions, Wageningen University and Research Centre, The Netherlands.

Ojiem, J. O., de Ridder, N., Vanlauwe, B., \& Giller, K. E. (2006). Socio-ecological niche: a conceptual framework for integration of legumes in smallholder farming systems. International Journal of Agricultural Sustainability, 4, 79-93.

Olson, R. A., \& Dreier, A. F. (1956). Fertilizer placement for small grains in relation to crop stand and nutrient efficiency in Nebraska. Soil Science Society of America Journal, 20, 19-24. http://dx.doi.org/10.2136/sssaj1956.03615995002000010005x

Otsyula, R., Rachier, G., Ambitsi, N., Juma, R., Ndiya, C., Buruchara, R., \& Sperling, L. (2004). The use of informal seed producer groups for diffusing root rot resistant varieties during period of acute stress. Addressing Seed Security in Disaster Response: Linking relief with development (pp. 69-89). Cali, Colombia: International Center for Tropical Agriculture (CIAT).

Peterson, H. L., \& Kremer, R. J. (1989). Compatibility of Rhizobia and fertilizers combined as legume inocula. World Journal of Microbiology and Biotechnology, 5, 95-104. http://dx.doi.org/10.1007/BF01724964

Prithiviraj, B., Zhou, X., Souleimanov, A., Kahn, W. M., \& Smith, D. L. (2003). A host-specific bacteria-to-plant signal molecule (Nod factor) enhances germination and early growth of diverse crop plants. Planta, 216, 437-445.

Raaijmakers, J. M., Paulitz, T. C., Steinberg, C., Alabouvette, C., \& Moënne-Loccoz, Y. (2009). The rhizosphere: a playground and battlefield for soilborne pathogens and beneficial microorganisms. Plant and Soil, 321, 341-361. http://dx.doi.org/10.1007/s11104-008-9568-6 
Ribet, J., \& Drevon, J. J. (1996). The phosphorus requirement of N2 fixing and urea-fed Acacia mangium. New Phytologist, 132, 383-390. http://dx.doi.org/10.1111/j.1469-8137.1996.tb01858.x

Robson, A. D., O'hara, G. W., \& Abbott, L. K. (1981). Involvement of phosphorus in nitrogen fixation by subterranean clover (Trifolium subterraneum L.). Australian Journal of Plant Physiology, 8, 427-436. http://dx.doi.org/10.1071/PP9810427

Rota, J. A., Wandahwa, P., \& Sigunga, D. O. (2006). Land evaluation for soybean (Glycine max L. Merrill) production based on kriging soil and climate parameters for the Kakamega district, Kenya. Journal of Agronomy, 5, 142-150. http://dx.doi.org/10.3923/ja.2006.142.150

Rotaru, V., \& Sinclair, T. R. (2009). Interactive influence of phosphorus and iron on nitrogen fixation by soybean. Environmental and Experimental Botany, 66, 94-99. http://dx.doi.org/10.1016/j.envexpbot.2008.12.001

Russo, V. M., Russo, B. M., Peters, M., Perkins-Veazie, P., \& Cartwright, B. (1997). Interaction of Colletotrichum orbiculare with thrips and aphid feeding on watermelon seedlings. Crop Protection, 16, 581-584. http://dx.doi.org/10.1016/S0261-2194(97)00024-0

Salvagiotti, F., Barraco, M., Dignani, D., Sanchez, H., Bono, A., Vallone, P., ... Gudelj, V. J. (2013). Plant stand, nodulation and seed yield in soybean as affected by phosphate fertilizer placement, source and application method. European Journal of Agronomy, 51, 25-33. http://dx.doi.org/10.1016/j.eja.2013.06.006

Ssali, H., \& Keya, S. O. (1983). The effect of phosphorus on nodulation, growth and dinitrogen fixation by beans. Biological Agriculture and Horticulture, 1, 135-144. http://dx.doi.org/10.1080/01448765.1983.9754387

Stoddard, F. L., Nicholas, A. H., Rubiales, D., Thomas, J., \& Villegas-Fernandez, A. M. (2010). Integrated pest management in faba bean. Field Crops Research, 115, 308-318. http://dx.doi.org/10.1016/j.fcr.2009.07.002

Stout, M. J., Thaler, J. S., \& Thomma, B. P. H. J. (2006). Plant-mediated interactions between pathogenic microorganisms and herbivorous arthropods. Annual Review of Entomology, 51, 663-689. http://dx.doi.org/10.1146/annurev.ento.51.110104.151117

Tavernier, V., Cadiou, S., Pageau, K., Laugé, R., Reisdorf-Cren, M., Langin, T., \& Masclaux-Daubresse, C. (2007). The plant nitrogen mobilization promoted by Colletotrichum lindemuthianum in Phaseolus leaves depends on fungus pathogenicity. Journal of Experimental Botany, 58, 3351-3360. http://dx.doi.org/10.1093/jxb/erm182

Thaler, J. S., Fidantsef, A. L., Duffey, S. S., \& Bostock, R. M. (1999). Trade-offs in plant defense against pathogens and herbivores: a field demonstration of chemical elicitors of induced resistance. Journal of Chemical Ecology, 25, 1597-1609. http://dx.doi.org/10.1023/A:1020840900595

Thamer, S., Schadler, M., Bonte, D., \& Ballhorn, D. J. (2011). Dual benefit from a belowground symbiosis: nitrogen fixing Rhizobia promote growth and defense against a specialist herbivore in a cyanogenic plant. Plant and Soil, 341, 209-219. http://dx.doi.org/10.1007/s11104-010-0635-4

Thawornchaisit, U., \& Polprasert, C. (2009). Evaluation of phosphate fertilizers for the stabilization of cadmium in highly contaminated soils. Journal of Hazardous Materials, 165, 1109-1113. http://dx.doi.org/10.1016/j.jhazmat.2008.10.103

Thuita, M., Pypers, P., Herrmann, L., Okalebo, R.J., Othieno, C., Muema, E., \& Lesueur, D. (2012). Commercial rhizobial inoculants significantly enhance growth and nitrogen fixation of a promiscuous soybean variety in Kenyan soils. Biology and Fertility of Soils, 48, 87-96. http://dx.doi.org/10.1007/s00374-011-0611-z

Tittonell, P., \& Giller, K. E. (2013). When yield gaps are poverty traps: The paradigm of ecological intensification in African smallholder agriculture. Field Crops Research, 143, 76-90. http://dx.doi.org/10.1016/j.fcr.2012.10.007

van Veen, J. A., van Overbeek, L. S., \& van Elsas, J. D. (1997). Fate and activity of microorganisms introduced into soil. Microbiology and Molecular Biology Reviews, 61, 121-135.

Were, H. K., Kabira, J. N., Kinyua, Z. M., Olubayo, F. M., Karinga, J. K., Aura, J., ... Torrance, L. (2013). Occurrence and distribution of potato pests and diseases in Kenya. Potato Research, 56, 325-342. http://dx.doi.org/10.1007/s11540-013-9246-9

Whipps, J. M. (2001). Microbial interactions and biocontrol in the rhizosphere. Journal of Experimental Botany, 52, 487-511. http://dx.doi.org/10.1093/jexbot/52.suppl_1.487

Will, T., \& van Bel, A. J. E. (2006). Physical and chemical interactions between aphids and plants. Journal of 
Experimental Botany, 57, 729-737. http://dx.doi.org/10.1093/jxb/erj089

Zafar, M., Abbasi, M. K., Rahim, N., Khaliq, A., Shaheen, A., Jamil, M., \& Shahid, M. (2013). Influence of integrated phosphorus supply and plant growth promoting rhizobacteria on growth, nodulation, yield and nutrient uptake in Phaseolus vulgaris. African Journal of Biotechnology, 10, 16781-16792.

Zhang, W., Ma, W., Ji, Y., Fan, M., Oenema, O., \& Zhang, F. (2008). Efficiency, economics, and environmental implications of phosphorus resource use and the fertilizer industry in China. Nutrient Cycling in Agroecosystems, 80, 131-144. http://dx.doi.org/10.1007/s10705-007-9126-2

\section{Copyrights}

Copyright for this article is retained by the author(s), with first publication rights granted to the journal.

This is an open-access article distributed under the terms and conditions of the Creative Commons Attribution license (http://creativecommons.org/licenses/by/3.0/) 